\title{
Feed Less, Earn More
}

\author{
By Matthew J. Ricketts
}

\section{Grazing longer and feeding less is key to improving ranch income. Here are profit improvement strategies to consider.}

$\mathrm{F}$ Teed and feeding is the number one cost of maintaining a cow herd. Producing, harvesting, baling, stacking, and then unstacking and feeding hay is not inexpensive. If the amount of hay fed could be reduced, the profitability of many ranches could be improved.

Feeding too much hay can often put you in a bind financially. Producing cattle that wean large calves often means selecting bulls and cows on the basis of what they can produce. This generally means a larger framed cow and/or higher milk production.

But eventually, both of these traits

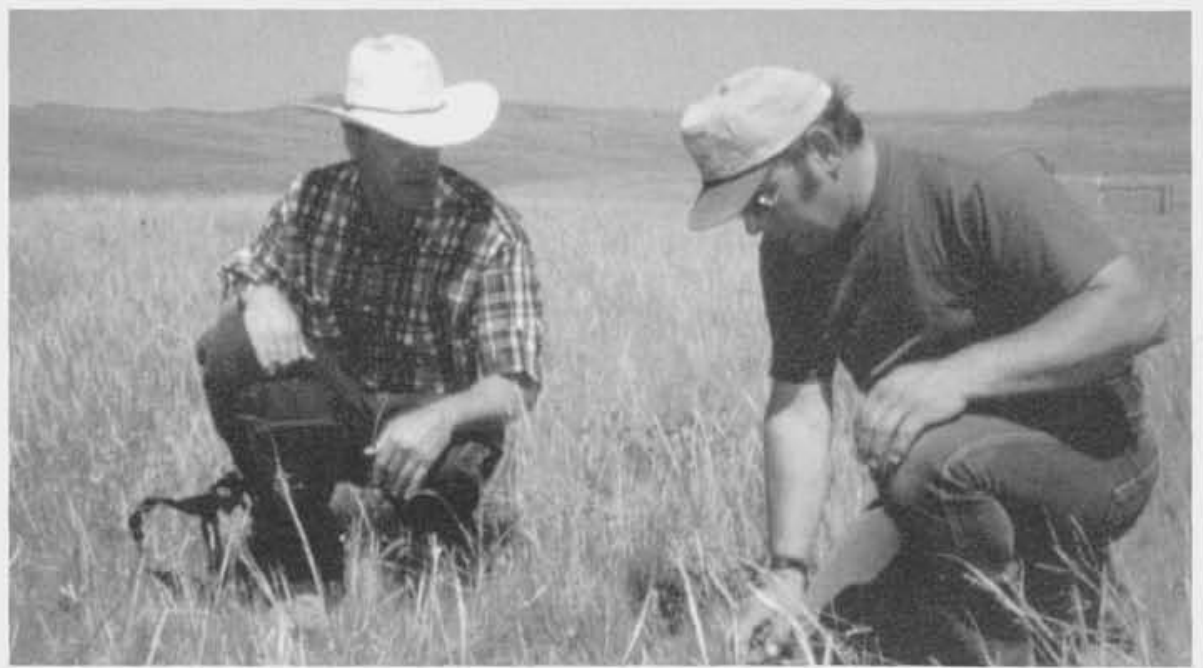

Knowing what nutrition is being provided to our range livestock by season is essential in order to improve ranch income and sustainability. Conducting nutritional assessments is key.

can translate into higher nutrient requirements. If these requirements outpace the ability of the rangeland or pasture to provide those nutrients at critical stages of production, the cow may come up dry or have related health problems. This translates into lower weaning percentages (the number one economic indicator for a cow/calf or ewe/lamb operator).

Are we spending big dollars for bulls that over the long term produce replacements that require more nutrients than our rangeland is able to provide year in and year out?

If profit equals production times price minus costs how do we optimize production at the least cost? (OPTIMIZE is the key word.) We need to conduct nutritional assessments of our least expensive and most abundant feed source-rangeland.

the most important factor in fertility, good health, and high reproductive rates. Most problems with reproduction are associated with insufficient nutrition, particularly protein and energy (Spitzer 1986).

In the spring of 1995 we began assessing the nutritional value of the least expensive and most abundant feed source available to Western ranchers - rangeland.

We sought to examine if feed costs could be cut and sufficient nutrition provided by shifting calving dates and conducting nutritional assessments.

This project centered on fecal profiling to predict livestock energy and protein intake (Stuth et al. 1989, Coleman et al. 1989, Lyons and Stuth 1991, Lyons et al. 1992, 1993, Coates 1998). Thirty ranchers in the sedimentary plains and the foothills regions of Montana collected samples.

Livestock performance was then evaluated based on the forage quality, environmental conditions, breed type, age, sex, physiological stage, body condition, and performance goals using the Nutritional Balance Analyzer computer program (NUTBAL) (Ranching Systems Group 1993). With this information a rancher could make more informed feeding or supplementation decisions or adjust his or hers grazing program to improve the overall economic and resource conditions on their ranch.

The sedimentary plains are characterized by rolling grassland intermixed with occasional rocky bluffs and ponderosa pine. Precipitation in 


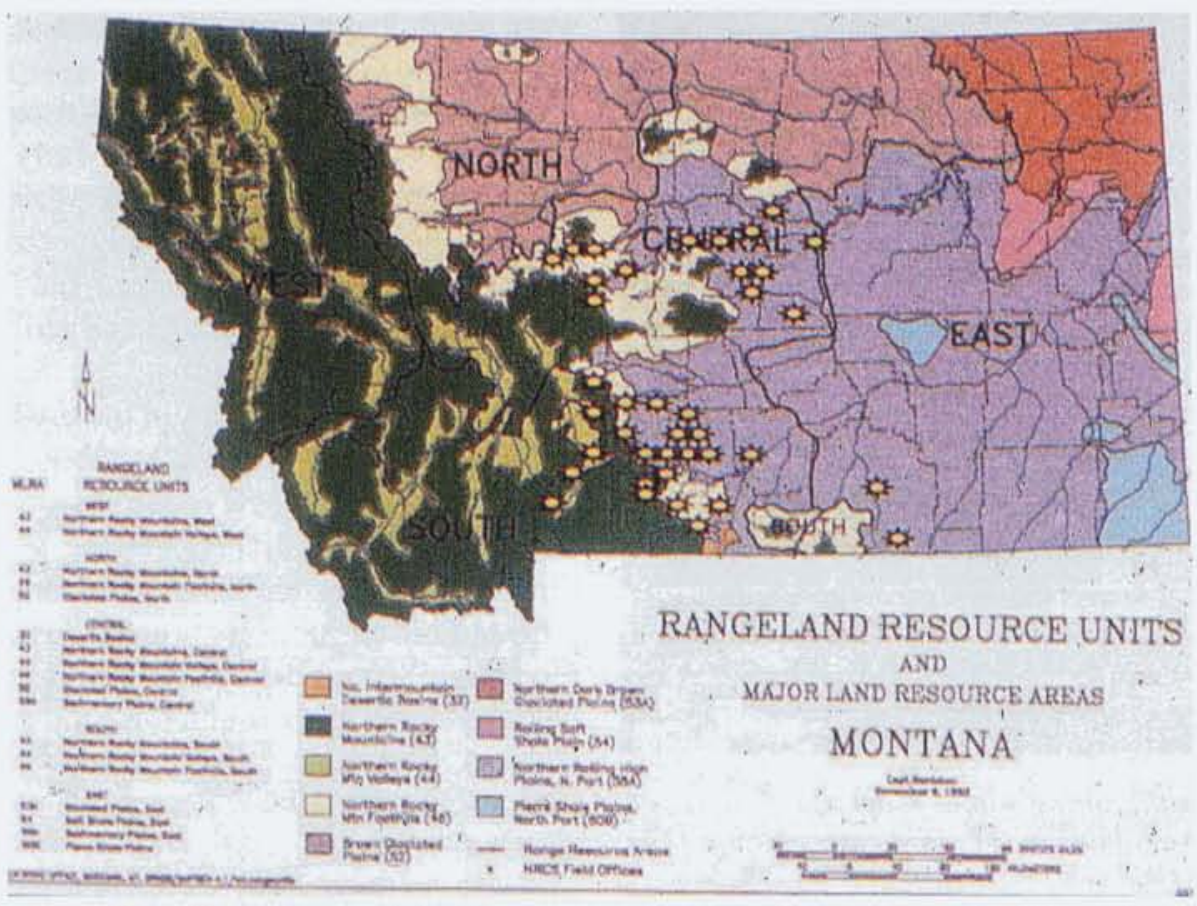

Location of ranches participating in rangeland quality assessments. The yellow represents the foothills region and the purple is the sedimentary plains region.

this region is between 12 " to 14 " on average. The characteristic plants include bluebunch wheatgrass, western and thickspike wheatgrass, needleandthread grass, blue grama, prairie junegrass, green needlegrass, fringed sagewort, dotted gayfeather, and scattered Wyoming big sage.

The Northern Rocky Mountain Foothills are characterized by steeply to gently sloping grassland

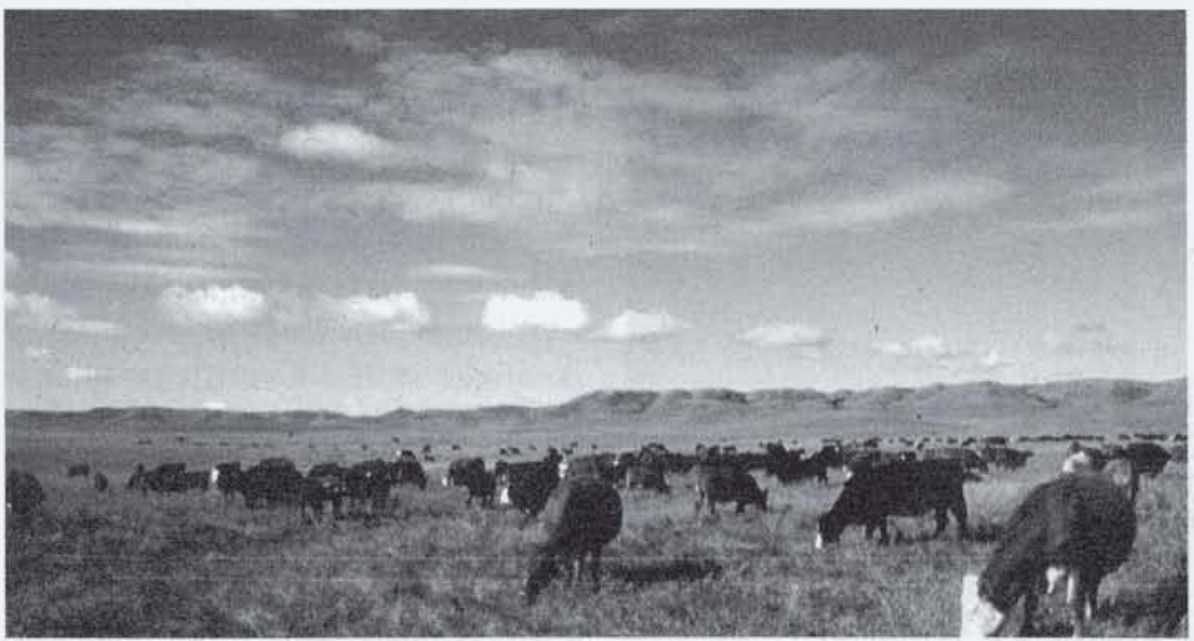

Quality along with quantity affect the productivity and profitability of livestock operations. Cattle pictured here are grazing in the sedimentary plains region near Billings, Montana.
Both regions receive $70 \%$ of their total precipitation in the growing season, with $35 \%$ falling during the months of May and June. Temperatures vary between -35 degrees $F$ in the winter to 95 degrees $\mathrm{F}$ in the summer for both regions.

We plotted the fecal sample results for protein and TDN (Total Digestible Nutrients), and compared them to livestock requirements.

\section{Consider Matching Calving Dates To Forage}

Overall TDN, or energy, was not deficient. However, protein was deficient at various times of the year.

In the Sedimentary Plains, IP (Intake Protein) could be less than optimum at any time of the year with winter being the most likely time to experience deficits, followed by summer, fall, and then spring.

Many ranchers in the plains are calving in March. If calving dates were shifted two to four weeks to mid-March or April, feeding costs could be cut significantly, and profitability improved by matching the nutrients available in the forage with the cow's nutrient requirements.

Energy was not a problem as long as sufficient standing forage was available and protein and energy were properly balanced in the diet.

The digestible organic matter / crude protein ratio is the ratio of digestible organic matter (or energy) to protein in the animal's diet. Animal performance is generally affected negatively when the ratio falls below four or rises above eight. In the plains we found it to rise above eight quite often. This was associated with dry periods and protein deficiencies. It almost never fell below four (a washy forage condition with high rumen degradable protein) which may account for Montana's so called 'hard grass'.

The typical cow body condition score (BCS) for the plains was between 4 to 6 . On the 1 to 9 scale, 


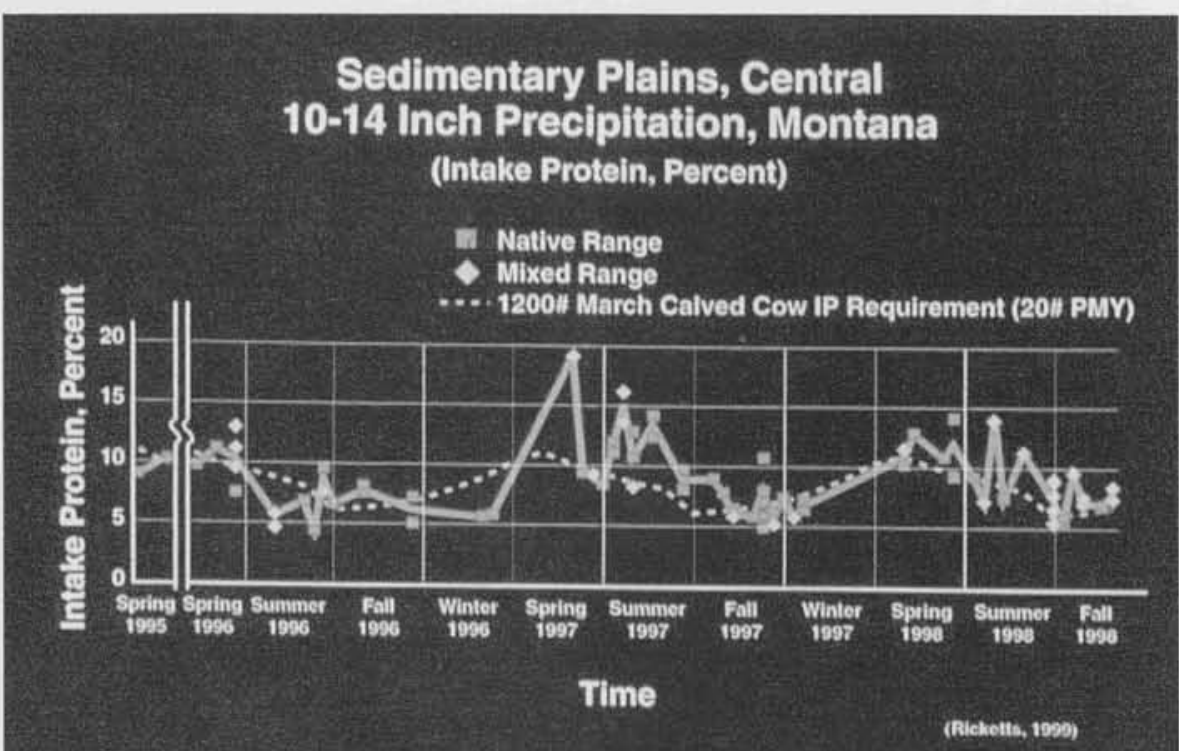

Shifting calving two to four weeks later in the spring would better match livestock nutrient requirements with forage nutrient availability in the sedimentary plains. (The graph reflects a March calved 20\# peak milk yield cow).

with 1 being extremely thin and 9 sloppy fat, a 5 or 6 at calving time is recommended to maintain a productive herd (healthy calves and timely breed back) (Richards et al. 1986).

In the foothills, intake protein could also be less than optimum at any time of the year with winter being the most likely time, followed by early spring, fall and summer.

Many ranchers are calving in February in the foothills. If calving dates were shifted eight weeks to

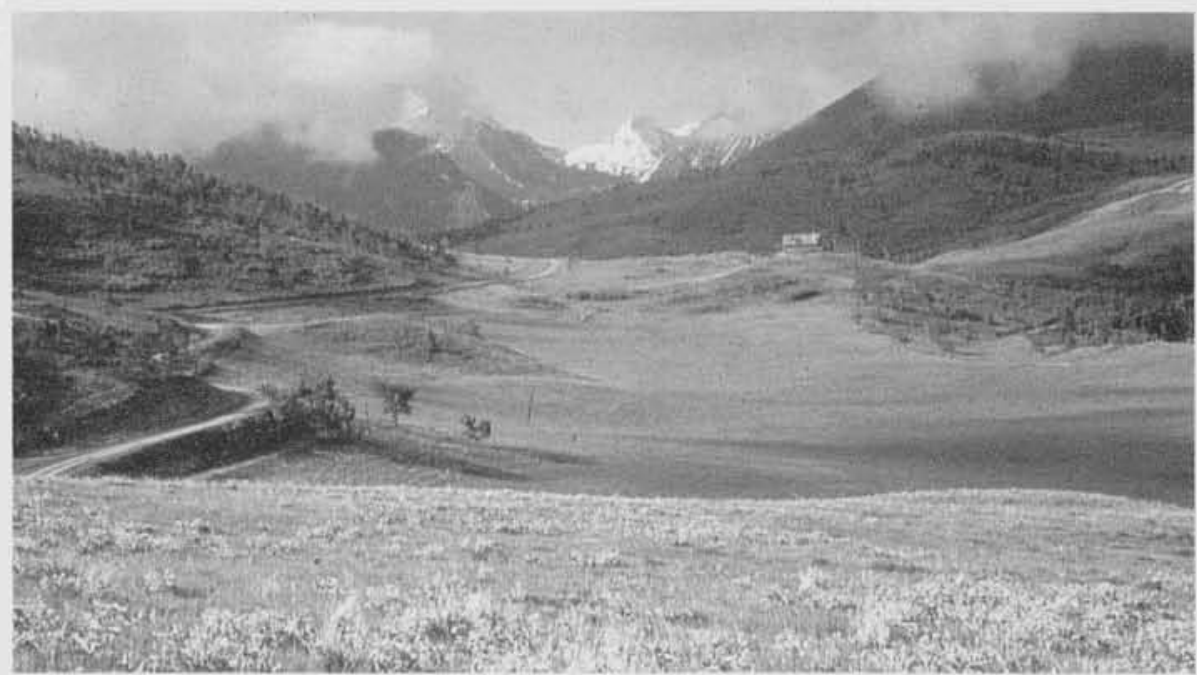

Foothills region in the spring near Livingston, Montana. were much less of a problem than in the plains

The typical cow body condition score was between 5 to 8 . Many ranchers are maintaining some expensive body condition on their cows, and could cut their feed bills with nutritional assessments and still maintain herd productivity.

In Nebraska a reduction in the cost of keeping a cow by synchronizing feed resources and cow requirements has been achieved (Proceeding of the Range Beef Cow Symposium 1997). This reduction in costs was more than enough to offset the reduced income from lighter weaning weights.

The hayland once being used to raise winter feed could be shifted to summer pastureland. Expensive machinery, as it wears out, may not have to be replaced, saving money.

\section{Utilize The Forages Available}

Knowing the quality of the different forages by season growing on your ranch can help to match grazing and calving dates so as to optimize the use of the available forage protein (Ricketts 1994) and still maintain high reproductive rates and weaning percentages.

When range condition declines, animal performance is impacted.

Range producing closer to its potential provides a greater total amount of energy and protein than range that is far below its potential.

In the Montana foothills rough fescue can dominate (high TDN and about $5 \%$ crude protein in the winter). Bluebunch wheatgrass can also dominate in the foothills or plains (high TDN and between 3 to $4 \%$ crude protein in the winter). Both of these species are tall statured and can provide excellent winter forage.

Shrubs are important nutritionally in the plains. Palatable shrubs help maintain protein at proper levels in the animal's diet when grasses and forbs are deficient in protein. This 
enables plains rangelands (that have these shrubs) to maintain animal performance at similar levels com-

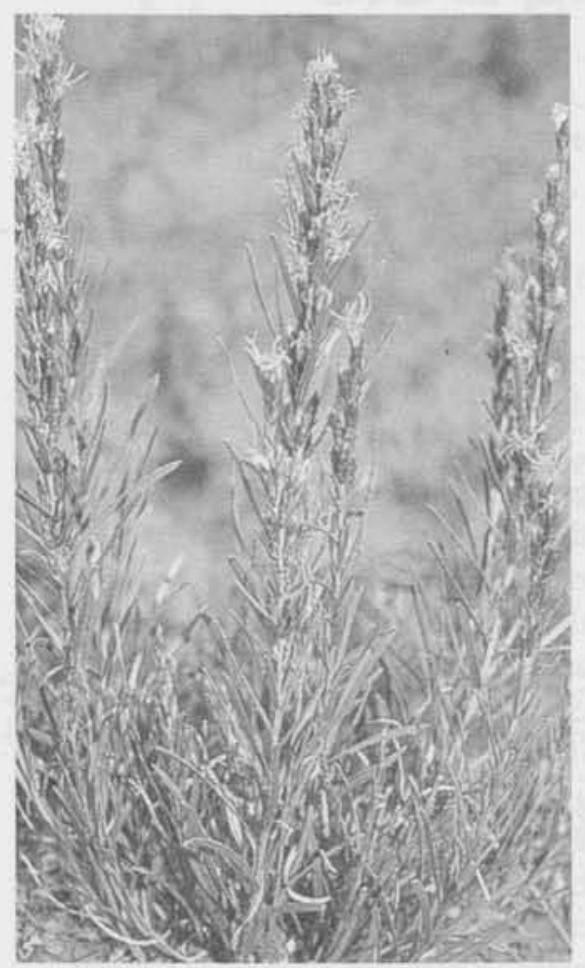

Dotted gayfeather and forbs similar to it are like little protein blocks scattered across the range. They provide needed nutrients to assist animals in digesting the associated high-energy grasses that may be deficient in protein.

pared to the foothills rangelands.

Greasewood is a palatable shrub that contains about $12 \%$ crude protein (cp) in the winter. Nuttlals saltbush is around $13 \% \mathrm{cp}$, and winterfat is around $13 \% \mathrm{cp}$ in the winter. Both are very palatable.

Forbs are also important. Purple prairie clover and dotted gayfeather are palatable warm season forbs containing around $25 \% \mathrm{cp}$ when green. They are like little protein blocks scattered on the landscape.

Sampling for intake protein and energy intake can help with strategically supplementing protein. Fecal sampling (Stuth et al. 1989) is a cost and time effective means for assessing protein intake of range livestock.

By not over or under supplement- ing protein, optimum herd productivity can be maintained, while cutting wintering costs and optimizing summering costs, and while maintaining adequate forage intake.

\section{Five Strategies To Consider}

In summary, to graze longer and feed less, five management areas should be considered:

1) Cattle should be bred for moderate frame and moderate milk production, and conditioned to rustle (work the hills, not the feed bunk). The cows have to fit the environment, the resources, and the management practices on the ranch.

2) Shift calving later to about midMarch or April.

3) Conduct nutritional assessments on a regular basis.

4) Balance forage availability with livestock requirements.

5) Overall, good range management that promotes a productive, vigorous, and diverse plant community can improve the long-term profitability and sustainability of livestock operations.

Matthew J. Ricketts is Area Rangeland Management. Specialist USDA-NRCS, Livingston, Montana.

\section{References}

Coates, D.B. 1998. Predicting diet digestibility and crude protein content from the feces of grazing cattle. Meat Research Corp./CSIRO, Final Report: Project CS. 253. CSIRO Tropical Agriculture, Queensland, Australia.

Coleman, S.W., J.W. Stuth, and J.W. Holloway. 1989. Monitoring the nutrition of grazing cattle with near-infrared analysis of feces. p. 881-882. In: XVI Internat. Grassl. Congr., Nice, France.

Lyons, R.K. and J.W. Stuth. 1991. Procedures for processing cattle fecal samples for NIRS analysis. Anim. Feed Sci. Technol. 35:21-36.

Lyons, R.K. and J.W. Stuth. 1992.
Fecal NIRS equations predict diet quality of free ranging cattle. J. Range Manage. 45:614-618.

Lyons, R.K., J.W. Stuth, J.E. Huston and J.P. Angerer. 1993. Predictions of the nutrient composition of the diets of supplemented versus unsupplemented grazing beef cows based on near-infrared reflectance spectroscopy of feces. J. Anim. Sci. 71:530-538.

Proceeding of the Range Beef Cow Symposium, 1997. Contact: Don Adams, University of Nebraska, North Platte 69101.

Ranching Systems Group. 1993. Nutritional Balance Analyzer User's Guide. Dept. of Rangeland Ecology and Management. Texas A\&M University. College Station, TX 77843-2126. USA. 148 pp.

Richards, M.W., J.C. Spitzer, and M.B. Warner. 1986. Effect of varying level of postpartum nutrition and body condition at calving on reproductive performance in beef cattle. J. Anim. Sci. 62:300-306.

Ricketts, M.J. 1994. Cutting ranching costs: optimizing forage protein value. Rangelands. 16:260-264.

Spitzer, J.C. 1986. Influences of nutrition on reproduction in beef cattle. In: D.A. Morrow (Ed.) Current Therapy in Theriogenology ( $2^{\text {nd }}$ Ed.). W. B. Saunders Co., Philadelphia.

Stuth, J.W., E.D. Kapes and R.K. Lyons. 1989. Use of near infrared spectroscopy to assess nutritional status of cattle diets on rangeland. pp. 889-890. In: Proc. XVI Internl. Grassl. Cong., Nice, France. 